\title{
Corporate Social Responsibility in the context of Female Foeticide and Infanticide in Rajasthan
}

\author{
Deepika Thakur* and Anukrati Sharma**
}

\begin{abstract}
In today's world, the success and recognition of a business has come to be associated with the way it carries out its corporate social responsibility (CSR). CSR is gaining popularity these days because of various reasons: to promote various brands of the company, social welfare, to uplift the reputation of a company, to comply with legal obligations and so on. There are many ways by which the companies can conduct their CSR activities to help the society in large. In recent times, CSR has become an important factor to boost the goodwill of a company as well as indirectly increase the sales of the company's product. The present paper is an attempt to find out the purpose and benefits of using CSR in creating awareness and strategies to help stop the crime of female foeticide and infanticide in the state of Rajasthan. The paper also focuses on some major steps which have been taken in this direction by the companies. The paper highlights a new model which can be adopted by companies in the context of 'save girl child' campaigns.
\end{abstract}

Keywords: Corporate Social Responsibility, Female foeticide, Infanticide.

\subsection{Introduction}

The concept of Corporate Social Responsibility (CSR) has widened the role of companies in recent times; the belief being that whatever profit is generated by companies is because of the society in which the company exists and hence the company has a duty to pay back something to the society. Thus the scope of responsibilities of companies has increased from merely providing jobs and contributing towards the economy to issues related to environment and social health. CSR has become a major driving factor behind a company's goodwill and companies are striving hard to mark their global presence by focusing on CSR activities that help in the upliftment of society as a whole.

\footnotetext{
*Research Scholar, Faculty of Commerce and Management, University of Kota.

**Associate Professor, Faculty of Commerce and Management, University of Kota
} 
In India, the CSR initiatives have largely been limited to environment (plantations, less use of paper, recycling waste, etc.) and education and health of the underprivileged. Companies have undertaken various activities towards reducing environmental pollution, producing good quality products through a harmless mechanism, providing basic amenities to the underprivileged, education camps and constructing schools, opening hospitals and organising medical camps for building a healthy nation. Some of these measures have developed as programs which are being run by these corporate houses on the national level. However, there are some issues of the society which are dangerous and degrade our culture but are still either untouched or very little care is taken of them.

This paper draws the attention of the corporate world towards one such social issue of female foeticide and infanticide in Rajasthan. An issue which is a heinous crime but still it does not exist in CSR strategies of big corporate houses. Companies have not been paying heed to this issue which is a road to various other problems occurring in the society and is also hampering the human life balance. Female foeticide is a major social problem in India and over a period of time social discrimination against women and preference for sons has promoted it to a level where the census reports of India since 1981 to 2011 have recorded an increasingly masculine ratio with Punjab and Haryana topping the chart. The magnitude of the problem as mentioned in the LANCET Journal based at Canada and India states that 500,000 girls were being lost annually through sex selective abortions. With such alarming figures, the Government, NGOs and social activists have come forward and have taken various initiatives to stop this crime. Several Acts have been passed but have not been enforced strongly enough. Multiple campaigns have been launched to increase the awareness of this act. This problem was also highlighted in a popular TV show 'Satyamev Jayate' which focused upon the severity of this problem in Western Rajasthan.

With such a situation prevailing around us, it is a bit of surprise that the issue of female foeticide lies nowhere in the CSR initiatives of the companies. While the corporates are taking various initiatives towards the social and environmental development, ${ }^{1}$ the issue of female foeticide and infanticide is something which requires more focus. This paper focuses upon what the Government, Corporates and social activists have done and are doing to curb this heinous crime, especially in Rajasthan. It also brings out some suggestions as to what more can be done to remove this from our society. 
74 | MANTHAN: Journal of Commerce and Management, Vol. 1, Issue 2

\subsection{Objectives}

The study intends to achieve the following objectives:

- To highlight the increasing problem of female foeticide and infanticide in Rajasthan.

- To find the reason behind the lack of support and initiative towards this problem in terms of Corporate Social Responsibility.

- To study and analyse the initiatives of Government and NGOs of Rajasthan towards curbing this heinous crime.

- To suggest measures which can be taken by companies in preventing these activities and making them a part of their CSR initiatives.

\subsection{Trends in Sex Ratio}

The census reports of Rajasthan show a wide gap between the male-female ratio. The census of 2001 depicted a picture where Rajasthan had 930 females per 1000 males in rural areas and 890 females per 1000 males in urban areas; on an average 921 females per 1000 males (Figure 1). This figure showed a slight difference in the census report of 2011 wherein Rajasthan had 933 females per 1000 males in rural areas and 914 females per 1000 males in urban areas; averaging 928 females per 1000 males. This can be considered as a progress.

Figure 1: Trends in Sex ratio (females per 1000 males) in Rajasthan

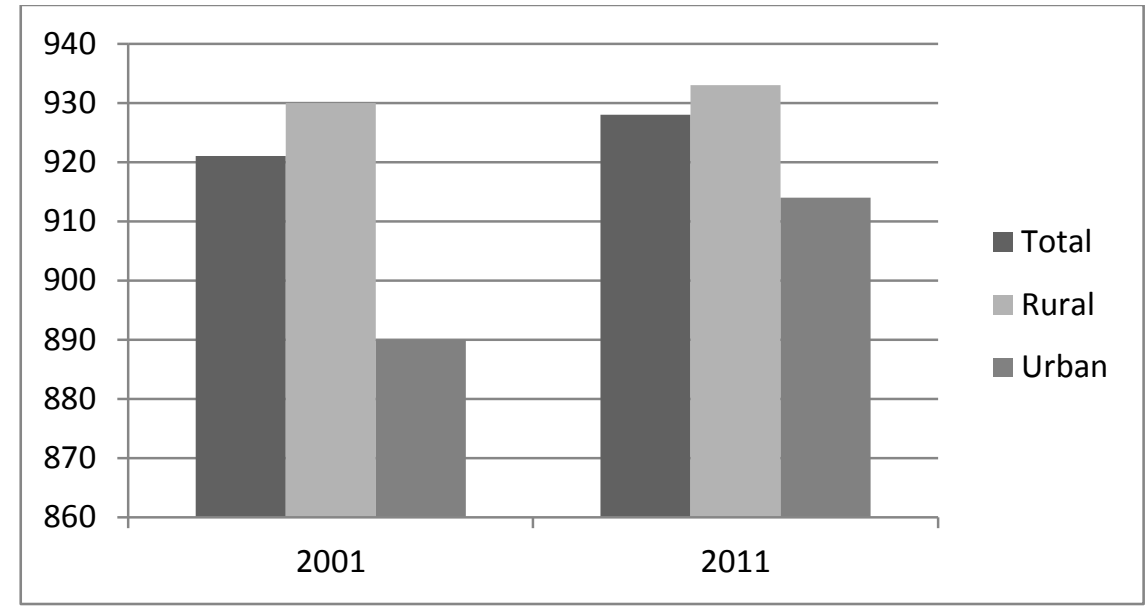

Source: censusindia.gov.in 
However, talking about sex ratio between 0-6 years, this figure has shown eye widening difference from 2001 to 2011. In 2001, there were 914 females per 1000 males in rural areas and 887 females per 1000 males in urban areas averaging 909 females per 1000 males (Figure 2). These figures drastically went down in the census report of 2011 which showed 892 females per 1000 males in rural areas and 874 females per 1000 males in urban areas giving an average figure of 888 females per 1000 males within the State.

Figure 2: Trends in Sex ratio (females per 1000 males) in age group 0-6 years in Rajasthan

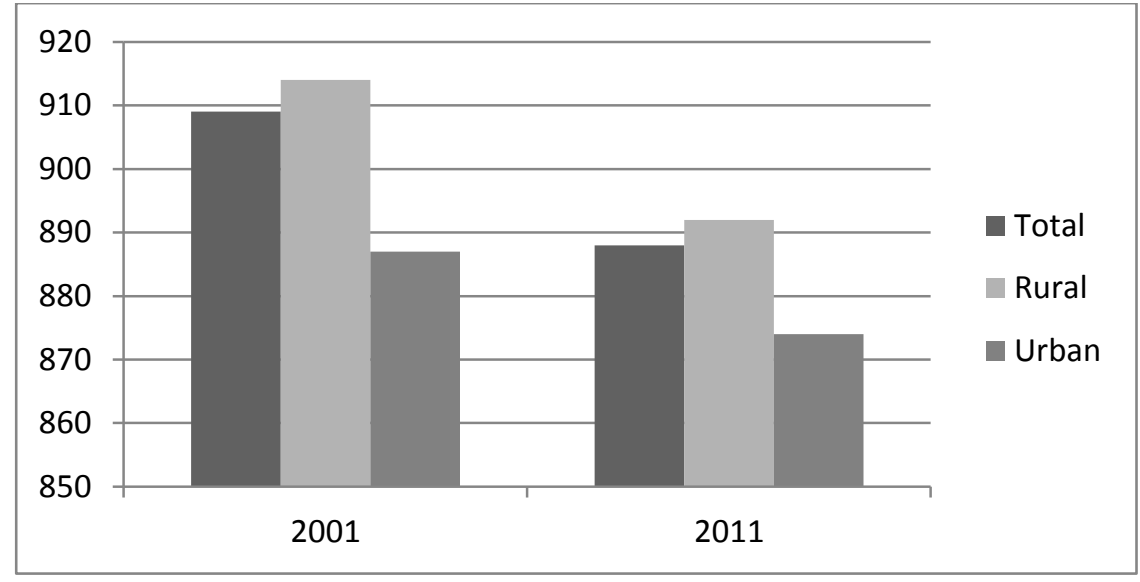

Source: censusindia.gov.in

These figures clearly state that the mortality rate of girl child has drastically increased in past 10 years and that too more in Urban India as compared to the Rural India. The problem of Female Foeticide \& Infanticide has aggravated in past 14 years and is still increasing. This is all because of better medical facilities available at Urban Areas. But the same is prevalent in the Rural India as well though they do not have modern techniques available there.

\subsection{Review of literature}

The idea of CSR first came up in 1953, when it became an academic topic in HR Bowen's 'Social Responsibility of the Business'. Since then there has been continuous 
debate on the concept and its implementation. [Parliament Library \& Reference, Research, Documentation \& Information Service (LARRDIS)]

The term Corporate Social Responsibility became popular in 1960s and has remained a term used indiscriminately by many to cover legal and moral responsibility more narrowly construed. CSR policy functions as a built-in, self-regulating mechanism whereby a business monitors and ensures its active compliance with the spirit of the law, ethical standards and international norms. At some places, CSR goes beyond compliance and engages in "actions that appear to further some social good, beyond the interests of the firm and that which is required by law.

One of the most contemporary definitions of CSR is from the World Bank Group, stating; "Corporate Social Responsibility is the commitment of businesses to contribute to sustainable economic development by working with employees, their families, the local community \& society at large, to improve their lives in ways that are good for business and for the development." (LARRDIS). Many authors affirm that businesses are an integral part of society and have a critical and active role to play in the sustenance and improvement of healthy ecosystems, in fostering social inclusiveness and equity and in upholding the essentials of ethical practices and good governance.

Proponents argue that corporations make more long term profits with CSR. This also makes business sense as companies with effective CSR, have image of socially responsible companies. They achieve sustainable growth in their operations in the long run and their products and services are preferred by customers. Some others argue that it distracts from the economic role of business and that it is merely window dressing or an attempt to pre-empt the role of Government as watchdog over powerful multinational corporations.

Different authors and organizations have framed different definitions for CSR with some commonalities . Baker (2004) defines CSR as "CSR is about how companies manage the business processes to produce an overall positive impact on society" (Baker, 2004). A publication by World Business Council for Sustainable Development defined CSR as "corporate social responsibility is the continuing commitment by business to behave ethically and contribute to economic development while improving the quality of life of the workforce and their families as well as of the local community and society at large." (Holme \& Watts, 2000)

Today, organizations that want to achieve long term success must consider what is known as the Triple Bottom Line: Profit, Planet and People. CSR as a strategic practice is a key to organizational success because it is one of the few practices that can positively impact all three elements of the Triple Bottom Line, contributing to a healthy 
bottom line \& long term sustainability. The benefits of an effective CSR approach to an organization can include:

- Stronger performance \& profitability.

- Improved relations with investment community and access to capital.

- Enhanced employee relations and company culture.

- Risk Management and access to social opportunities.

- Stronger relationships with communities \& legal regulators.

CSR is concerned with treating the stakeholders of the firm ethically or in a responsible manner. 'Ethically and responsibly' means treating stakeholders in a manner deemed acceptable in civilized societies. Stakeholders exist both within a firm and outside. The natural environment is a stakeholder. The wider the aim of social responsibility is to create higher \& higher standard of living, while preserving the profitability of the corporation, for people both within and outside the corporation. CSR therefore means the ethical behavior of business towards its constituencies or stakeholders. (Hopkins, 2004)

According to CII, in a global context there is no single universally accepted definition of CSR rather each definition that exists underpins the impact of businesses on society at a large. Although the roots of CSR lie in philanthropic activities of corporations such as donations, charity, reliefs work, etc. Globally the concept has evolved and encompasses all related concepts such as triple bottom line, corporate citizenship, philanthropy, shared value, corporate sustainability and business responsibility.

The European Commission defines CSR as "the responsibility of enterprises for their impacts on society." To completely meet their social responsibility, enterprises "should have in place a process to integrate social, environmental, ethical human rights and consumer concerns into their business operations and core strategy in close collaboration with their stakeholders." According to United Nations Industrial Development Organization, "Corporate Social Responsibility is a management concept whereby companies integrate social and environmental concerns in their business operations and interactions with their stakeholders". CSR is generally understood as being the way through which a company achieves the balance of economic, environmental and social imperatives (Triple-Bottom-Line Approach), while at the same time addressing the expectations of shareholders and stakeholders. In this sense, it is important to draw a distinction between CSR, which can be a strategic business management concept and charity sponsorships or philanthropy. Even though the latter can also make a valuable 
contribution to poverty reduction, will directly enhance the reputation of a company and strengthen its brand, the concept of CSR clearly goes beyond that.

CSR in India has traditionally been seen as a philanthropic activity. And in keeping with the Indian tradition, it was an activity that was performed but not deliberated. As some observers have pointed out the practice of CSR in India is still remains within the philanthropic space, but has moved from institutional building (educational, research \& cultural) to community development through various projects. The Companies Act, 2013 has introduced the idea of CSR to the forefront and through its disclose-or-explain mandate, is promoting greater transparency and disclosure. CSR is the soul of every business today and has also become the password to not only overcome competition but ensure sustainable growth.

\subsection{Approaches towards CSR in India}

There are varied approaches of CSR in different countries; for instance, it is said that for the Chinese consumers, a socially responsible company makes safe and high quality products. For Germans, CSR means providing secure employment. In South Africa, it makes a positive contribution to social needs such as health care and education. In general, the common approach to CSR is corporate philanthropy; which includes monetary donations and aid given to promote health, social welfare and the environment among others.

In India, the concept of CSR is governed by clause 135 of the Companies Act, 2013, which was passed by both Houses of Parliament. The Act lists out a set of activities eligible under CSR. Companies may implement these activities taking into account the local conditions after seeking board approval. The activities are mentioned in the Schedule VII of the Act are:

- Promotion of education

- Eradication of extreme hunger and poverty.

- Reducing child mortality and improving maternal health.

- Gender equity and women empowerment.

- Environmental sustainability

- Combating HIV-AIDS, malaria and other diseases.

- Employment enhancing vocational skills

- Social business projects.

- Such other matters as may be prescribed. 
The Act prescribes that a CSR committee of the Board should be constituted. It should consist of at least three directors out of whom at least one is an independent director. This composition will be disclosed in the Board's report as per sub section (3) of section 134. The CSR committee shall :

- Formulate and recommend a CSR policy to the board, indicating the activities as specified in schedule VII of the Act.

- Recommend the amount of expenditure to be incurred on the activities indicated in the policy.

- Monitor the CSR policy regularly.

The Indian CSR Model has been explained in Figure 3.

Figure 3: The Indian CSR Model.

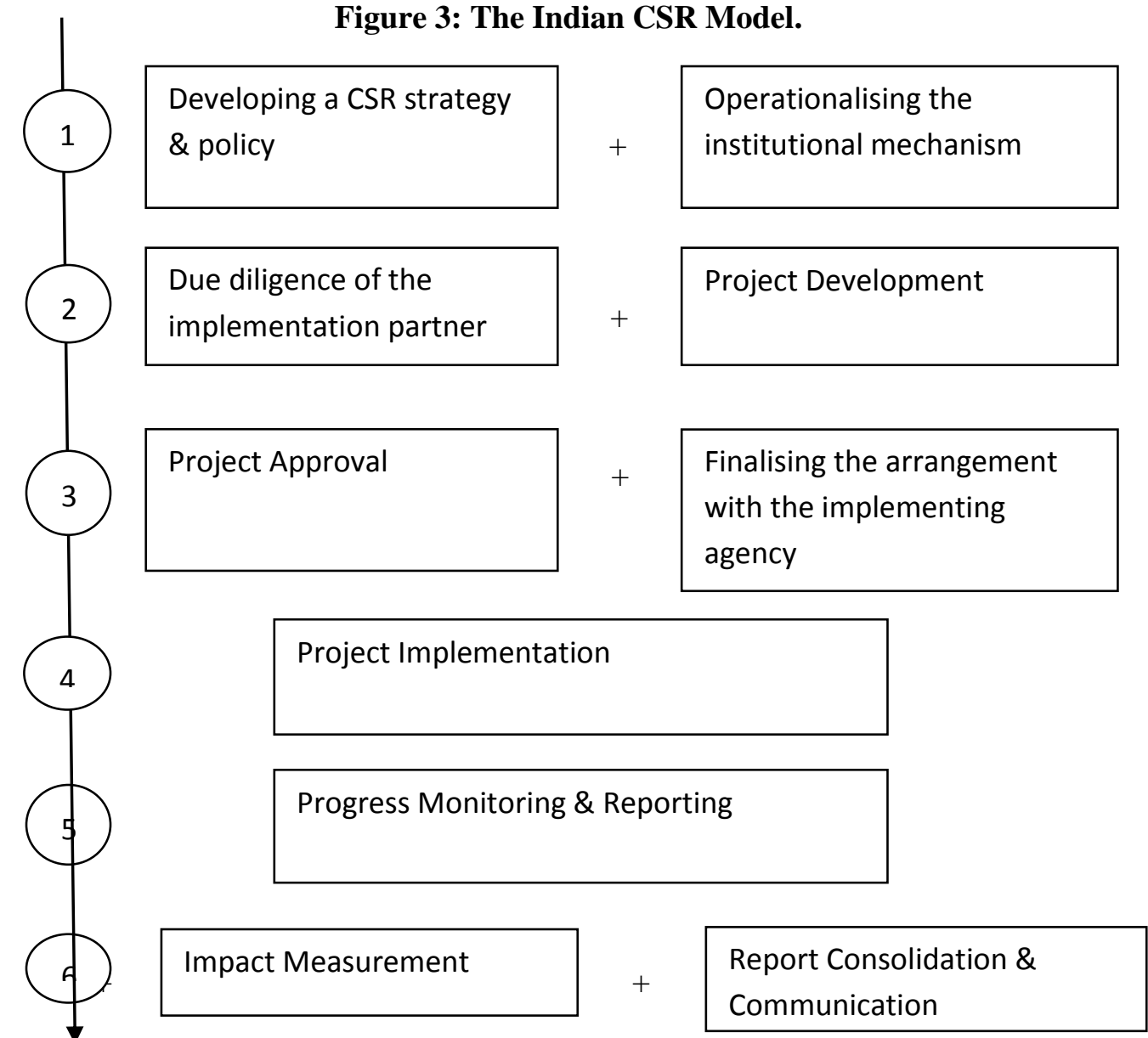

Source: Handbook on Corporate Social Responsibility, published by Confederation of Indian Industry 


\subsection{Initiatives so far}

\subsection{Government Initiatives}

With the new company law making it obligatory for corporate India to conduct CSR activities, India can become an international benchmark for CSR activities. From April 1, 2014, the new law under the Companies Act, 2013 will require entities with a profit of Rs. 5 crore or more; or a net worth of Rs. 500 crore or more; or an annual turnover of Rs. 1,000 crore or more have to spend $2 \%$ of their profits on real time CSR activities. This is the first legislation of its kind in the world. Over 16,200 entities will undertake CSR Activities from this year under section 135 of the Companies Act. This Law is being implemented not to transfer Government responsibility to Corporate Sector; rather to supplement and compliment what the Government is doing.

The Supreme Court of India have given directives to the Centre and all the States to supervise the implementation of Dowry Prohibition Act \& Medical Termination of Pregnancy Act, 1971 for which a committees which would meet at least once in six months. The committees should gather information regarding breach of the provisions of Act and take legal actions against people violating them. The committees should ensure that all the Medical Units must be registered and manufacturers and sellers should not sell any of the ultra-sonography machines to the unregistered centre. The authorities should seize the machines used illegally and should be confiscated under the code of Criminal Procedure. Further, the courts should dispose of all the pending cases within 6 months. Government has launched a scheme, the Janani Suraksha Yojana, wherein a sum of Rs. 1400 is given for every baby delivered in the hospital.

\subsection{Initiatives by NGOs and Social Activists}

The Shanti Project: Shanti Project seeks to promote the economic and social well-being of marginalised women and children, bridging resources and needs by providing a forum for stagnating traditions and skills. Shanti seeks not only to break free the chains of poverty, but to encourage empowerment. The team is working day and night in Jaisalmer and nearby areas working upon women liberalization and empowerment which includes the issue of female foeticide and infanticide happening there. On the other hand, a local community of Jodhpur naming Ghanchi community has decided to open a bank account for every new born girl and put Rs. 5000 in it as a fixed deposit. Again this step is taken to reduce the high incidences of female foeticide and infanticide in Rajasthan. This will be implemented among the hundred families of Ghanchi Community in Jodhpur city. 
The main objective behind this initiative is to ease the financial burden on families at the time of the girl's marriage. This effort is worth appreciating.

Priyanka Chopra Foundation for health and education: Actor Priyanka Chopra has been actively involved in various causes related to girl child for many years now. Along with NDTV-Vedanta's campaign - Our Girls, Our Pride; she is also the Brand Ambassador of UNICEF's Goodwill Ambassador for India. Her Foundation is focused towards providing support to the unprivileged girls across the country.

\subsection{Corporate Initiatives}

Vedanta: Vedanta Group has launched a campaign named KHUSHI- Our Girls Our Pride. "Girls are not born by choice but by chance" is the mind set that prevails in the Indian society and this need to be broken. Therefore with a view to build a life of dignity for the girl child, Vedanta Group and NDTV has joined hands and launched this campaign. The campaign was launched on $19^{\text {th }}$ August 2013, in New Delhi, addressing the key issues like nutrition, education, health, foeticide and infanticide. In the same context, they organised an event at Udaipur, Delhi, Mumbai and Kolkata simultaneously where hundreds of children painted canvases on the 'Pride of Girl Child'. Udaipur set the record with 600 school children participating in it. They painted their hearts out wherein, they painted women athletes, mother's womb, girls as mother, as school children, sister, and creator of life. The focus of the campaign will be to educate people at large, bring awareness, bring policy changes and sensitize people towards girl child and build a respect for the gender.

\subsection{Findings and suggestions}

1) During the research, it was found that though the Clause 135 of Companies Act mentions that gender equity and women empowerment is an area of concern and companies should take initiatives towards it, are only few initiatives taken towards this social cause.

2) The figures on sex ratio in Rajasthan indicate that the practice of female foeticide and infanticide is prevalent more in urban areas than rural areas. Bose (2007) in his address on India's Unborn Daughters: Victims of Demographic Terrorism, stated three major reasons for the spread of female foeticide: i) road connectivity, ii) availability of doctors with ultrasound machines, iii) the client's capacity to pay for the cost of test and abortion.

3) It was also observed that this practice is undertaken more by the Literate class of people, thereby questioning the education setup of our country. 
82 | MANTHAN: Journal of Commerce and Management, Vol. 1, Issue 2

4) Though the Government has taken initiatives in curbing this act, but tracking its implementation at the grass root level is a difficult task.

5) There are lot of initiatives that been taken in this respect by NGOs and social activists but corporate participation is very less. Companies need to play a major role towards economic development and overall growth of our nation; therefore with regard to their social responsibility, they should focus upon curbing the gender inequalities prevailing in our society, along with environment protection and sustainable growth.

6) It needs to be ensured that the medical facilities in the country are not unethically used. For the same, doctors have to practice medicine ethically and not allow sex determination of foetus.

7) We would like to suggest that corporates can start taking small initiatives like the Ghanchi community of Jodhpur has taken. They can introduce any scheme for their female workers having girl child which can include, opening an account or fixed deposit of certain amount; or may be free education up to a certain level; creating employment opportunities specially for women; starting more and more awareness campaigns in the regions where they exist.

8) Figure 4 lays down a model that we suggest to deal with this problem.

Figure 4: A Model to Reduce in Female Foeticide and Infanticide

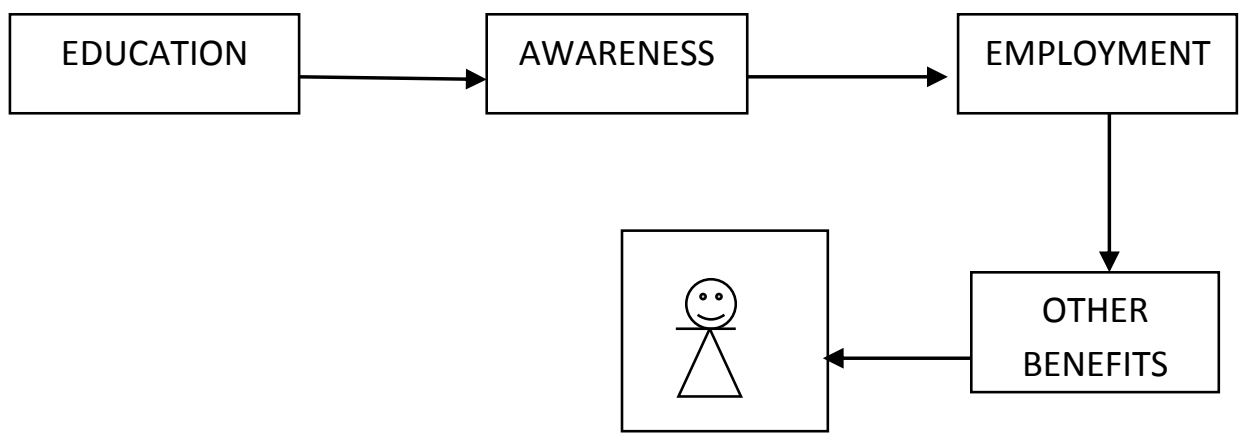

Source: Model suggested by authors

Note: In the above suggested model 'Other Benefits' refers to - employment quota for females in the corporate. Special Monetary benefits to the female employees who girl child. Sufficient number of leaves to the female employees as given in the Government sector. Financial aid to females at lowest rates. Female concessions in different services. 


\subsection{Conclusion}

Gender equality is one of the key issue that needs serious attention. Increasing female foeticide and infanticide depicts a negative picture of our nation in the world. While our nation is improving in terms of medical facilities, we are an education hub and our cultural heritage is our strength; but we need to work more on ethics and human values which form the basis of our existence. A lot has been done by various people and organisations towards saving our girl child but there is long way to go to eradicate this difference of male and female and companies can play a major role in this as they are present in almost every part of our nation.

\section{Endnotes}

1. Some notable efforts of big Corporate houses in this direction include the following: (i) the Axis Bank foundation runs Balwadis which are learning places for children living in large urban slum clusters along with skill development programs like motor driving, welding, mobile repairing, tailoring, etc for the youth in backward districts; (ii) Companies like Bharat Petroleum Corporation, Hindalco Industries, Indian Oil Corporations have undertaken initiatives regarding prevention of water in various States of India. Their only motto is to turn draught stricken areas to Water Positive; (iii) Tata Consultancy Services \& Tata Steel are undertaking rigorous initiatives towards adult education and health. The TATA Steel Rural Development Society is aiming towards improving the agricultural productivity \& raise the standard of living of the Farmers.

\section{References}

Baker, Mallen. (2004). Blog on Corporate Social Responsibility - What does it mean? First published on $8^{\text {th }}$ June, 2004. www.mallenbaker.net/csr/definition.php

Bose, Ashish. (2007). India's Unborn Daughters - Victims of Demographic Terrorism, Keynote Address, National Level Seminar on Gender Issues and Empowerment of Women on the Occasion of Platinum Jubilee of Indian Statistical Institute, Kolkata during 2006-2007.

Handbook on Corporate Social Responsibility (2013), published by Confederation of Indian Industry.

Holme, Richard \& Watts, Phil. (2000). Making Good Business Sense. Published by The World Business Council for Sustainable Development on Corporate Social Responsibility. 
84 | MANTHAN: Journal of Commerce and Management, Vol. 1, Issue 2

Hopkins, Michael. (2004). Corporate Social Responsibility: An issues paper. Working Paper No. 27 Policy Integration Department, World Commission on the Social Dimension of Globalization, International Labour Office Geneva.

Inputs from Dr. Nainani Mohini - Gynecologist, Kota (Rajasthan)

Inputs from Dr. Kabra Shashank - Radiologist; Camberwell Diagnostic \& Research Centre, Jaipur (Rajasthan)

Reference Note No. 11, Parliament Library \& Reference, Research, Documentation \& Information Service (LARRDIS) 2013.

Rajasthan's Daily Newspapers.

\section{Web References}

- www.csrwire.com

- www.unio.org

- www.india-inc.in/csr.html

- http://ec.europa.eu/enterprise/policies/sustainable-business/corporate-socialresponsibilty/index_en.htm

- www.khushi-creatinghappiness.blogspot.in

- www.ndtv.com/article/cities/rajastha-community-to-offer-rs-5000-to-everynewborn-girl-296930

- www.satyamevjayate.in

- www.SchemaAdvisory.com

- www.theshantiproject.org

- http://censusindia.gov.in/2011census/censusinfodashboard/stock/profiles/en/IND008 _Rajasthan.pdf 